\title{
Convalescence of auditory brainstem response following idiopathic sudden onset sensorineural hearing loss
}

\author{
Przywrócenie słuchowych potencjałów wywołanych pnia mózgu w nagłym idiopatycznym \\ niedosłuchu czuciowo-nerwowym
}

\author{
${ }^{1}$ Department of Otorhinolaryngology, Head \& Neck Surgery, Hospital Tawau, P0 Box 67, 91007 Tawau, Sabah, Malaysia \\ 2 Department of Otorhinolaryngology, Head \& Neck Surgery, School of Medical Sciences, Universiti Sains Malaysia Health Campus, 16150 Kubang Kerian, Kelantan, Malaysia \\ Correspondence: Khairunnisak Misron, Department of Otorhinolaryngology, Head \& Neck Surgery, Hospital Tawau, P0 Box 67, 91007 Tawau, Sabah, Malaysia, tel.: 0137260616, e-mail: nis875@gmail.com
}

Abstract Sudden onset sensorineural hearing loss is an emergency condition in otorhinolaryngology. Despite its common occurrence, the investigation and treatment of this condition are still controversial. Auditory brainstem response is one of hearing assessment tools used in sudden onset sensorineural hearing loss. However, its findings may be false positive at early stages of the disorder, leading to unnecessary investigations and treatments. We report two cases of idiopathic sudden onset sensorineural hearing loss, which manifested in abnormal auditory brainstem response during the acute phase of illness. However, a complete recovery of auditory brainstem response was observed after treatment completion. Therefore, we suggest that auditory brainstem response should be performed reasonably, especially during the acute phase of sudden onset sensorineural hearing loss.

Keywords: sudden hearing loss, sensorineural, auditory brainstem response

Streszczenie Nagły idiopatyczny niedosłuch czuciowo-nerwowy jest stanem nagłym w otorynolaryngologii. Pomimo częstego występowania badanie i leczenie tego zaburzenia nadal budzą kontrowersje. Jednym z narzędzi diagnostycznych stosowanych u pacjentów z nagłym idiopatycznym niedosłuchem czuciowo-nerwowym jest pomiar słuchowych potencjałów wywołanych pnia mózgu. Badanie to może jednak dawać wyniki fałszywie dodatnie we wczesnych stadiach choroby, prowadząc w konsekwencji do niepotrzebnych dalszych badań i prób leczenia. W pracy przedstawiono dwa przypadki nagłego idiopatycznego niedosłuchu czuciowo-nerwowego objawiającego się nieprawidłowościami w zapisie słuchowych potencjałów wywołanych pnia mózgu podczas ostrej fazy choroby. Po zakończeniu leczenia stwierdzono całkowite przywrócenie słuchu w badaniu słuchowych potencjałów wywołanych pnia mózgu. Autorzy zalecają wykonywanie tego badania w sposób racjonalny, w szczególności podczas ostrej fazy choroby.

Słowa kluczowe: nagła głuchota idiopatyczna, czuciowo-nerwowa, słuchowe potencjały wywołane pnia mózgu 


\section{INTRODUCTION}

udden onset sensorineural hearing loss (SSNHL) is defined as sudden onset of hearing loss of $30 \mathrm{~dB}$ or more over three consecutive audiometric frequencies occurring within 72 hours ${ }^{(1)}$. The incidence of this condition is estimated between 5 and 20 persons per 100,000 per year ${ }^{(2)}$. Although many theories have been proposed to explain the aetiology of SSNHL, the cause could be identified in only $7-45 \%$ of cases, and most of them are idiopathic ${ }^{(2,3)}$. All patients with SSNHL should be evaluated for deafness characteristics using pure tone audiometry (PTA).

TELINGA KANAN (R)

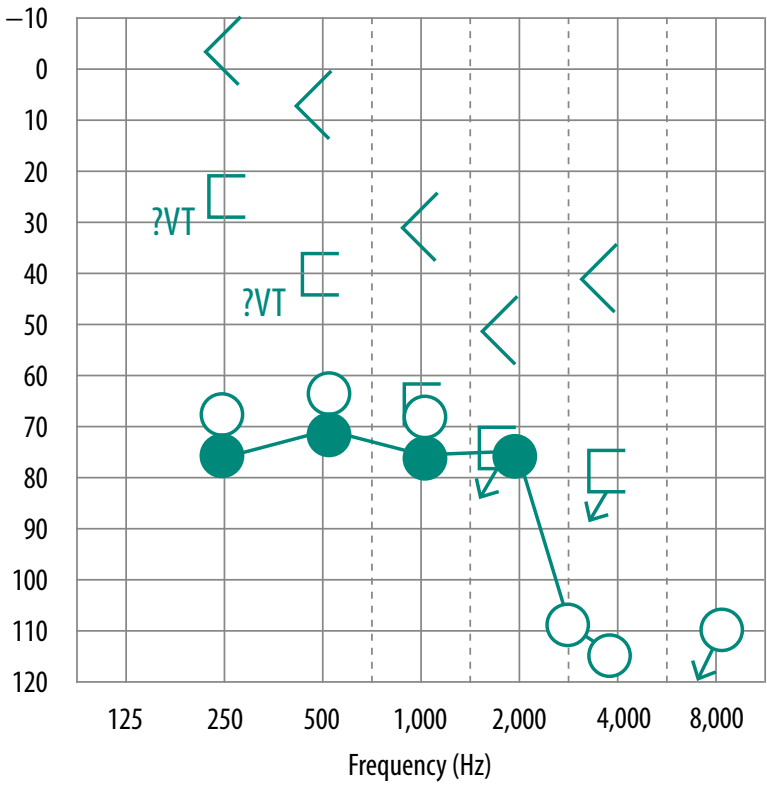

TELINGA KANAN (R)

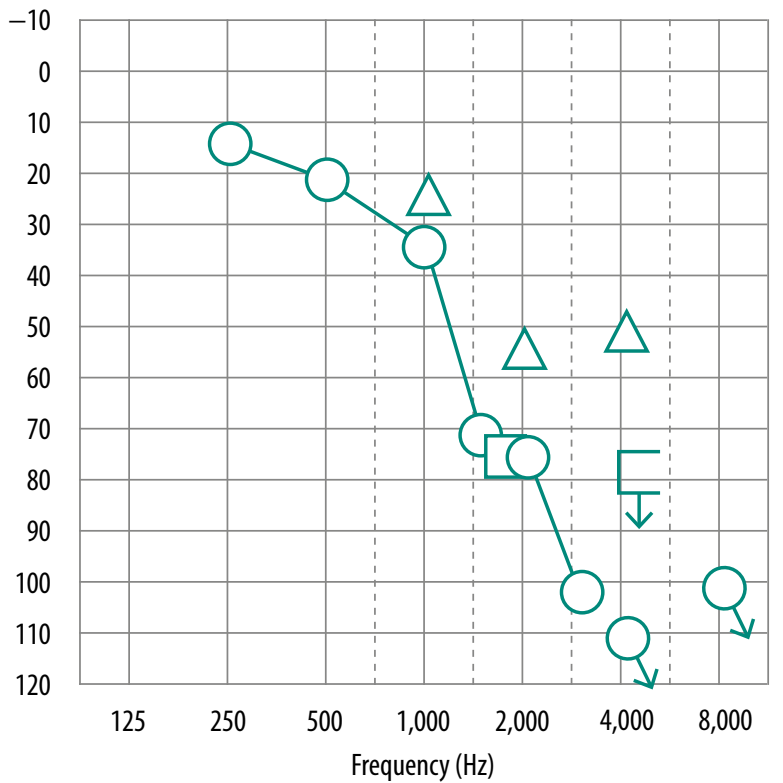

The role of auditory brainstem response (ABR) in assessing the presence of retrocochlear pathology in acute SSNHL is not well established even though its sensitivity is as high as the sensitivity of magnetic resonance imaging (MRI) in detecting a cerebellopontine angle tumour ${ }^{(4)}$.

\section{CASE REPORT}

\section{Case 1}

A 41-year-old healthy housewife presented with sudden onset reduced hearing in the right ear lasting 5 days, which

A

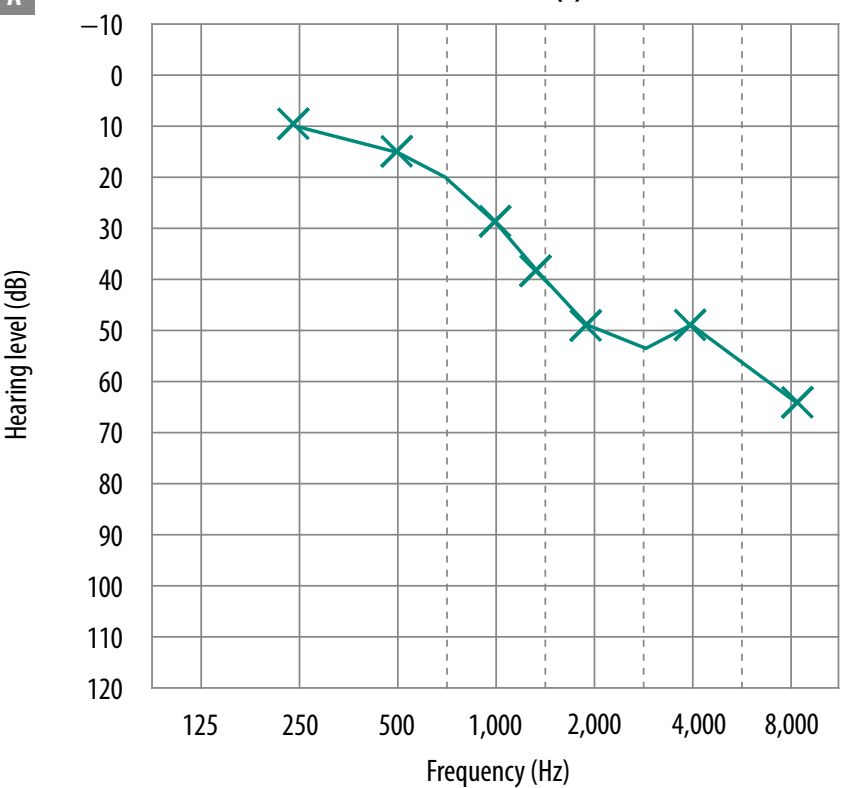

B

TELINGA KIRI (L)

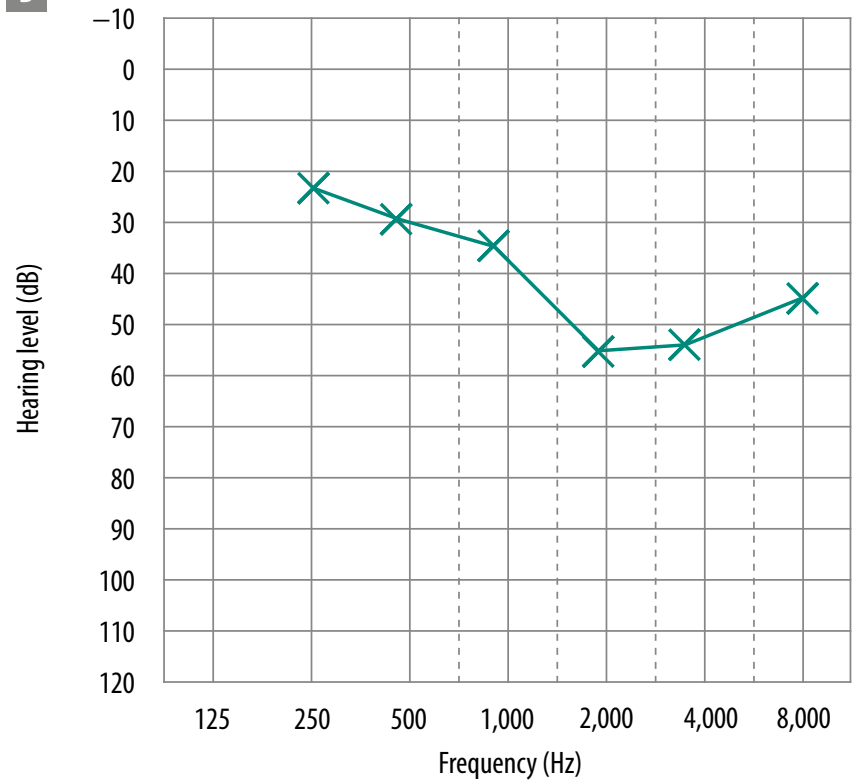

Fig. 1. PTA during initial presentation of hearing loss in case 1 (A) and after completion of steroid therapy approximately two weeks after (B) 

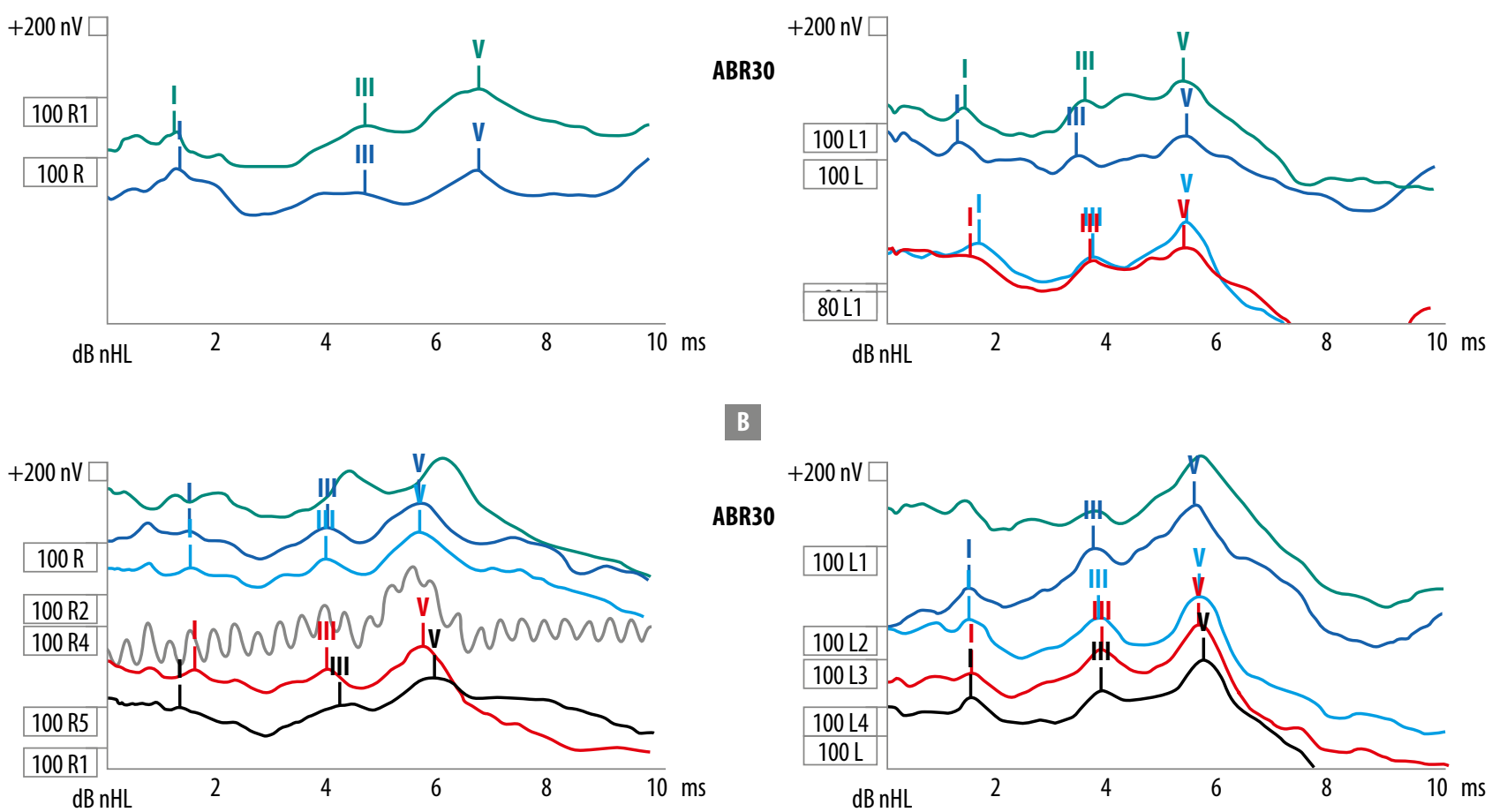

Fig. 2. Initial ABR in case 1 (A) and normal ABR following completion of steroid treatment (B)

appeared upon waking up from sleep. She denied any tinnitus, vertigo, otalgia and otorrhoea. There was no preceding history of fever, rhinitis or head trauma. Otherwise, she had no facial asymmetry or neurological deficit. Physical examination revealed no abnormalities. Otoscopic examination showed bilaterally normal tympanic membrane. The Rinne test was positive for both ears and Weber's test lateralised to the left ear. Nasoendoscopic examination revealed no significant findings. All cranial nerves except for the right vestibulocochlear nerve were intact.

PTA showed severe-to-profound sensorineural hearing loss in the right ear and mild sensorineural hearing loss in the left ear (Fig. 1 A). Tympanometry was type A bilaterally, indicating normal middle ear function. ABR demonstrated delayed interpeak latency between wave I to wave III and V, which were 4.67 and $6.73 \mathrm{~ms}$, respectively. On the other hand, interaural latency of wave III and wave $\mathrm{V}$ between both ears was also prolonged, which was 1.20 and $1.13 \mathrm{~ms}$ (Fig. $2 \mathrm{~A}$ ). Full blood count, renal profile, liver function test, fasting blood sugar, fasting lipid profile, thyroid function test, autoimmune screening were within normal limit. MRI of internal acoustic meatus and cerebellopontine angle was normal. The patient was assumed to have idiopathic SSNHL. She was started on intravenous dexamethasone $8 \mathrm{mg}$ thrice a day followed by tapering doses of oral prednisolone for 2 weeks.

A follow-up was performed in an otorhinolaryngology clinic after treatment completion. She claimed that her hearing of 2-week steroids demonstrated partial recovery of hearing (Fig. 1 B). ABR was performed upon completion of steroid therapy in view of partial improvement of hearing and normal MRI findings. Repeated ABR revealed normal findings, with the interpeak latency between wave I to wave III and V, which were 2.47 and $4.14 \mathrm{~ms}$, respectively. Interaural latency of wave III and wave V between both ears was also within normal ranges, i.e. 0.04 and $0.27 \mathrm{~ms}$ (Fig. $2 \mathrm{~B}$ ).

\section{Case 2}

A 25-year-old house officer with no known medical conditions experienced sudden onset hearing loss in his right ear for two days. There was mild intermittent tinnitus in the right ear. Otherwise, there was no vertigo, otalgia and otorrhoea. He denied recent upper respiratory tract infection or head trauma. On examination, the patient seemed comfortable. Otoscopic examination showed bilaterally normal tympanic membrane. Nasoendoscopic examination was normal. Other cranial nerves were intact.

There was evidence of right-sided mild-to-profound sensorineural hearing loss from the PTA. Other than that, there was normal hearing in the left ear (Fig. 3 A). Tympanometry showed type A bilaterally. ABR revealed delayed interpeak latency between wave I and V which was $5.47 \mathrm{~ms}$ in the right ear. The interaural wave $\mathrm{V}$ latency was also prolonged, i.e. $0.73 \mathrm{~ms}$ (Fig. $4 \mathrm{~A}$ ).

Full blood count, renal profile, liver function test, fasting blood sugar, fasting lipid profile, thyroid function 
TELINGA KANAN (R)

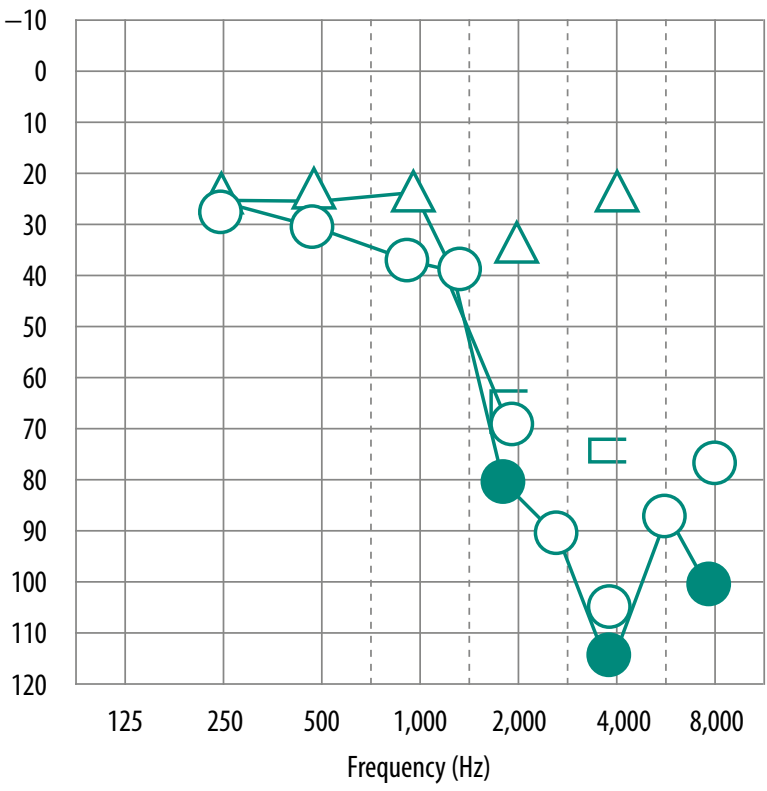

TELINGA KANAN (R)

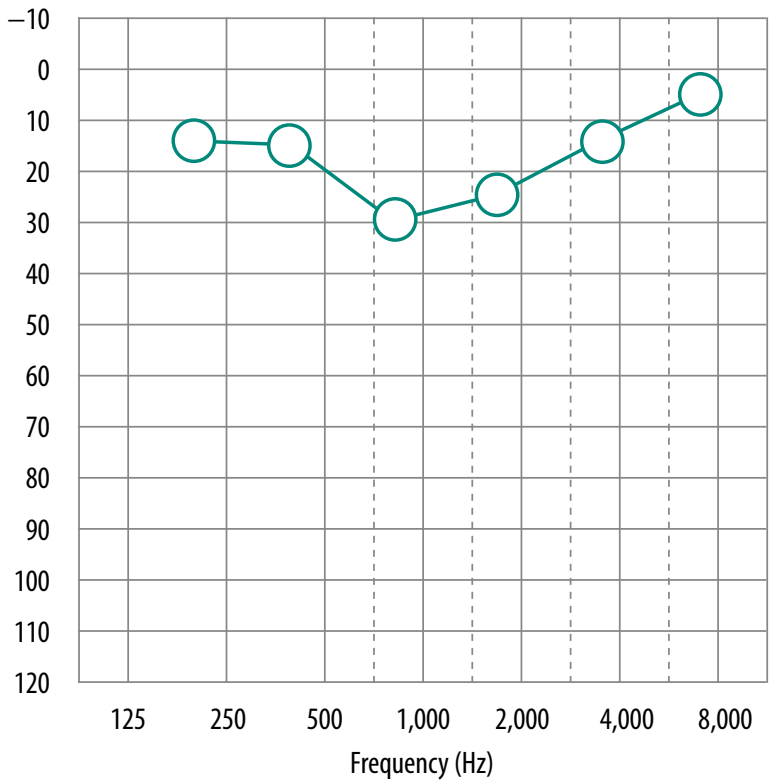

A

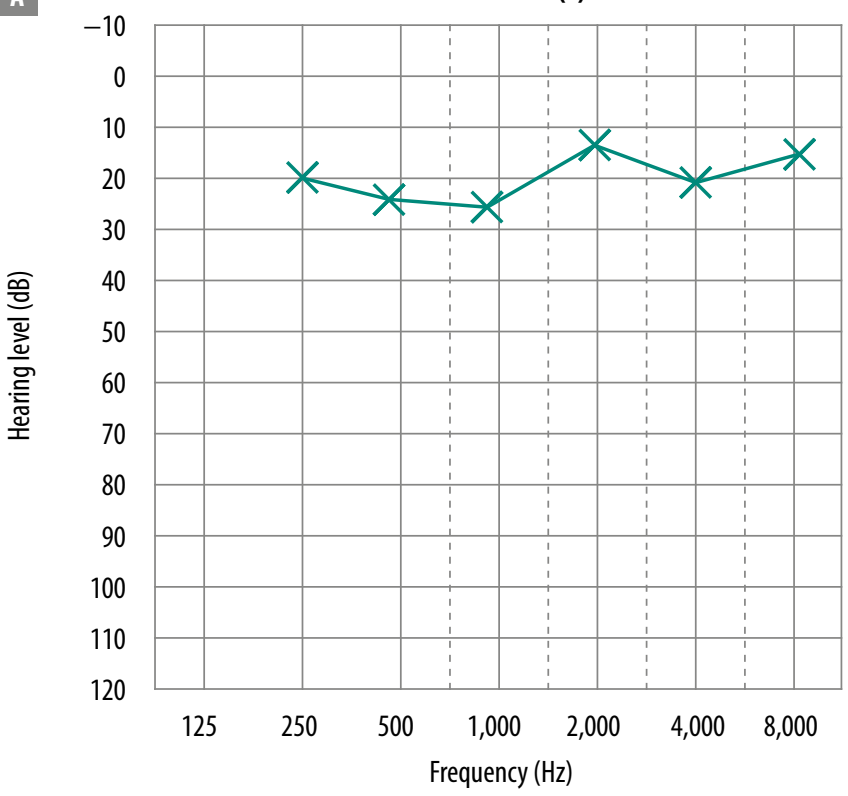

B

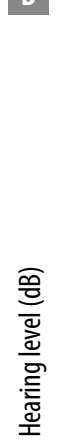

Fig. 3. PTA during initial presentation of hearing loss for case 2 (A) and after completion of steroid therapy approximately two weeks after (B)

test, autoimmune screening were within normal range. Idiopathic SSNHL was diagnosed. Intravenous dexamethasone $8 \mathrm{mg}$ thrice a day was commenced followed by tapering doses of oral prednisolone for 2 weeks.

Upon completion of steroid therapy, the patient reported that the hearing was normal and tinnitus resolved. Repeated PTA showed complete resolution of hearing loss in the right ear (Fig. 3 B). Further evaluation of ABR was performed due to the improvement of symptoms. Repeated ABR also reverted to normal. The interpeak latency between wave $\mathrm{I}$ and $\mathrm{V}$ was $4.33 \mathrm{~ms}$ in the right ear. The interaural wave $\mathrm{V}$ latency was $0.07 \mathrm{~ms}$ (Fig. $4 \mathrm{~B}$ ).

\section{DISCUSSION}

It is believed that inflammation originating from the inner ear structures occurs in the course of SSNHL. It is presumed that inflammation of the cochleovestibular nerve or cochlear neuritis leads to injury to this nerve, inducing neural changes as well as disrupting mechanoelectrical transmission and transduction. Schuknecht and Donovan described several microscopic changes in the temporal bone in 12 patients with idiopathic SSNHL. The findings revealed atrophy of the supporting cells of the organ of Corti as well as tectorial membrane and stria vascularis ${ }^{(5)}$. Perhaps this 


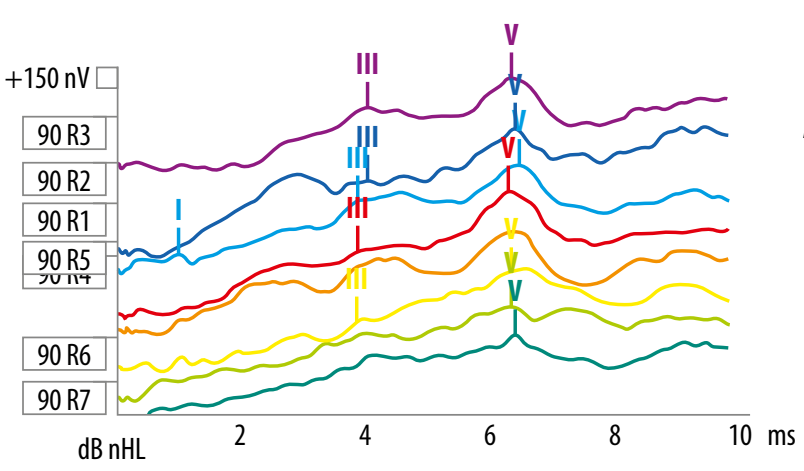

A
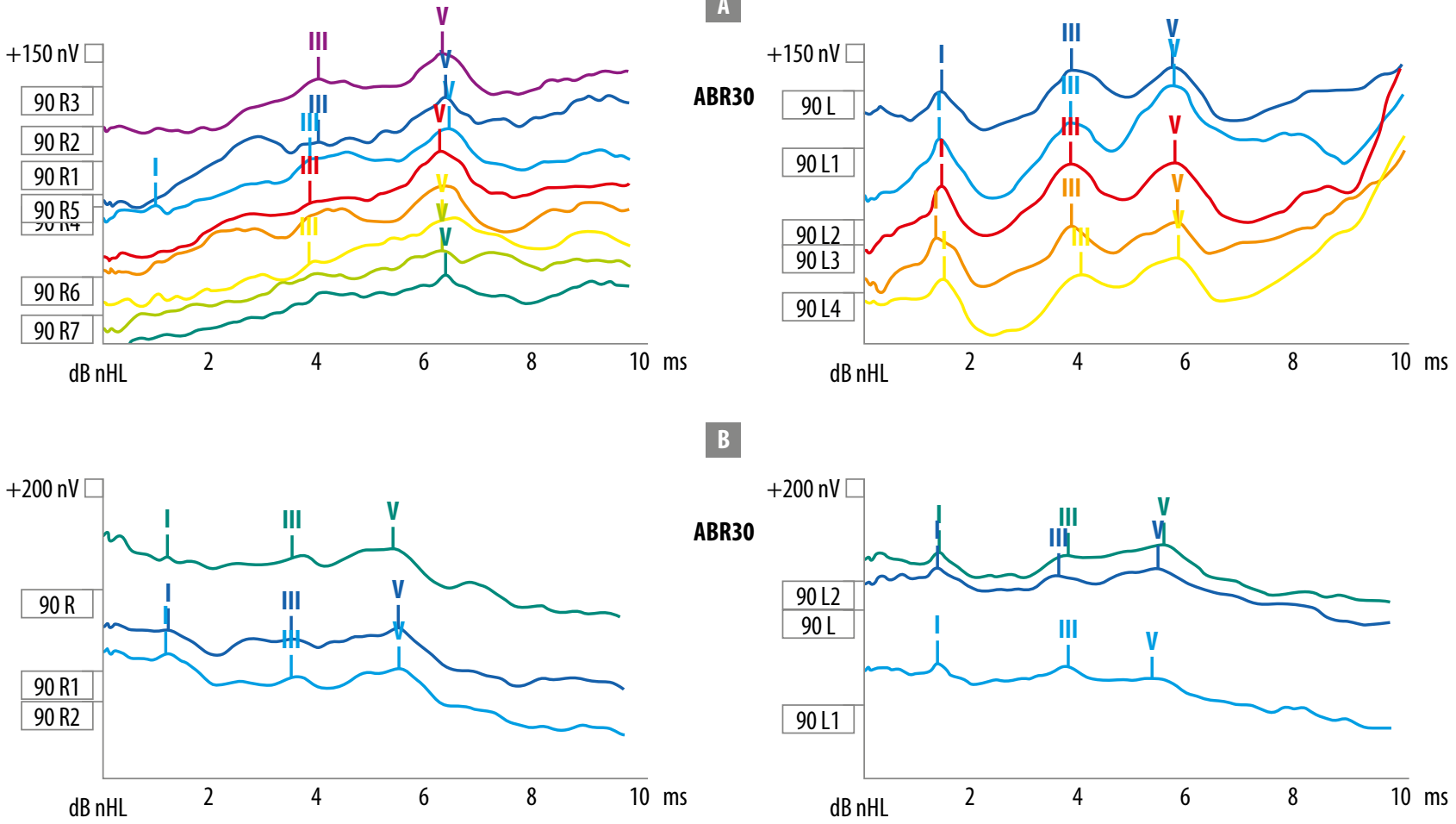

Fig. 4. Initial ABR for case 2 (A) and normal ABR following completion of steroid treatment (B)

condition has similar pathogenesis as neuropraxia, whereby there is focal demyelination and subsequently, disturbed nerve conduction without axonal degeneration. It is evidenced that the velocity of nerve conduction is reduced following acute nerve insult. Therefore, nerve conduction assessment should be performed 10-14 days after the acute nerve injury as the presence of distal response amplitude indicates recovery of the nerve injury ${ }^{(6)}$. As illustrated in our cases, repeated PTA after 2 weeks revealed complete recovery of the hearing without audiological deficit in one patient while the other patient showed partial recovery of hearing. These findings are in line with those presented by Moon et al., whereby it is estimated that hearing improvement in SSNHL is seen within 2 weeks after treatment ${ }^{(7)}$.

PTA is a standard investigation in diagnosing SSNHL. It provides degree, type and configuration of hearing loss. Some literature reports recommended ABR as an additional hearing test in SSNHL as it provides information regarding retrocochlear pathology characterised by interaural wave $\mathrm{V}$ difference between both ears more than $0.40 \mathrm{~ms}$ or prolonged interpeak latencies between wave I and V of more than $4.40 \mathrm{~ms}^{(8)}$. It has been reported that the incidence of vestibular schwannoma in SSNHL is estimated to account for $1-4 \%$ of cases ${ }^{(9)}$. Apart from that, the presence of prolonged wave I latency in ABR is found to be associated with poorer hearing outcome in SSNHL ${ }^{(10)}$. From our experience, both patients with SSNHL showed abnormal ABR during acute phase of illness, which was suggestive of a retrocochlear lesion. One of them no demonstrable abnormalities at the cerebellopontine angle or along the cochlear nerve. Serial PTAs showed complete recovery and partial recovery of hearing in the presented cases. Repeated ABR after completion of steroid therapy revealed normal findings in both patients. Similar findings were reported by Busaba and Rauch, in which a quarter of patients who developed SSNHL had abnormal ABR. Among those with abnormal ABR, only one patient showed abnormal MRI at the distal internal acoustic meatus; however, complete resolution was observed on repeated MRI after 6 weeks ${ }^{(11)}$.

The natural course of idiopathic SSNHL varies. Therefore, the proposed treatment for this condition is still controversial. To date, the role of pharmacological agents such as steroids, anti-inflammatory drugs, antibiotics, vasodilators, volume expanders and hyperbaric oxygen confer inconsistent results ${ }^{(2)}$. Although steroid administration is well accepted in clinical practice, it failed to show any significant efficacy when compared with placebo ${ }^{(3,12)}$. Besides, the benefits must outweigh the risks and potential side effects when using this drug. However, it was mentioned in literature that SSNHL patients with normal ABR findings showed better response to steroids as compared to patients with abnormal ABR findings. Among SSNHL patients with abnormal ABR, recovery of hearing was observed in $56 \%$ of patients on steroids. In contrast, hearing recovery was reported in only $20 \%$ of patients who did not receive steroid therapy ${ }^{(11)}$. These findings indicate that steroids play a role in the treatment of patients with SSNHL despite the presence of abnormal ABR during the initial phase of disease. 


\section{CONCLUSION}

The majority of patients with idiopathic SSNHL recover without any complications. Therefore, the authors suggest that it is reasonable to defer any special investigations such as ABR or MRI until treatment completion. This is because ABR may give false positive results during acute phase of SSNHL, probably due to the inflammation of the cochlear nerve. This seems important to avoid misdiagnosis resulting in costs and time consuming investigations. Although ABR seems to add no significant information during acute SSNHL, it is still recommended if serial PTA revealed non-recovery of hearing after treatment completion to exclude retrocochlear lesion.

\section{Conflict of interest}

The authors do not declare any financial or personal links to other persons or organisations that could adversely affect the content of this publication or claim rights thereto.

\section{References}

1. Wilson WR, Byl FM, Laird N: The efficacy of steroids in the treatment of idiopathic sudden hearing loss. A double-blind clinical study. Arch Otolaryngol 1980; 106: 772-776.

2. Kuhn M, Heman-Ackah SE, Shaikh JA et al.: Sudden sensorineural hearing loss: a review of diagnosis, treatment, and prognosis. Trends Amplif 2011; 15: 91-105.

3. Suckfüll M: Perspectives on the pathophysiology and treatment of sudden idiopathic sensorineural hearing loss. Dtsch Arztebl Int 2009; 106: 669-675; quiz 676.

4. Inoue Y, Kanzaki J, Ogawa K: Vestibular schwannoma presenting as sudden deafness. J Laryngol Otol 2000; 114: 589-592.

5. Schuknecht HF, Donovan ED: The pathology of idiopathic sudden sensorineural hearing loss. Arch Otorhinolaryngol 1986; 243: 1-15.

6. Quan D, Bird SJ: Nerve conduction studies and electromyography in the evaluation of peripheral nerve injuries. UPOJ 1999; 12: 45-51.

7. Moon IS, Kim J, Lee SY et al.: How long should the sudden hearing loss patients be followed after early steroid combination therapy? Eur Arch Otorhinolaryngol 2009; 266: 1391-1395.

8. Perkhidmatan Audiologi, Kementerian Kesihatan Malaysia: Prosedur operasi standard: penjagaan pesakit bermasalah retrokoklear [Malay language]. 2014.

9. Lin $\mathrm{C}$, Gong $\mathrm{Q}$, Zuo $\mathrm{W}$ et al.: The clinical characteristics and treatment for sudden sensorineural hearing loss with vestibular schwannoma. Eur Arch Otorhinolaryngol 2015; 272: 839-842.

10. Lin $\mathrm{HC}$, Chou YC, Wang $\mathrm{CH}$ et al.: Correlation between auditory brainstem response and hearing prognosis in idiopathic sudden sensorineural hearing loss patients. Auris Nasus Larynx 2017; 44: 678-684.

11. Busaba NY, Rauch SD: Significance of auditory brain stem response and gadolinium-enhanced magnetic resonance imaging for idiopathic sudden sensorineural hearing loss. Otolaryngol Head Neck Surg 1995; 113: 271-275.

12. Conlin AE, Parnes LS: Treatment of sudden sensorineural hearing loss: I. A systematic review. Arch Otolaryngol Head Neck Surg 2007; 133: 573-581. 